Jurnal ASPIKOM, Vol. 7, No. 1, January 2022, pp. 32-43

P-ISSN: 2087-0442, E-ISSN: 2548-8309

DOI: http://dx.doi.org/10.24329/aspikom.v7i1.1063

\title{
Fact-Checking and Check-Worthiness Determination on Tempo.co during Covid-19 Pandemic
}

\author{
Annisa Nurul Hanifah*, Zainuddin Muda Z. Monggilo \\ Department of Communication Science, Faculty of Social \& Political Sciences, \\ Universitas Gadjah Mada, Jalan Sosio Yustisia No. 1, Daerah Istimewa Yogyakarta \\ 55281, Indonesia \\ *Corresponding author, e-mail: nissahan07@gmail.com
}

\begin{abstract}
Fact-checking journalism appears with its purpose to improve the quality of information, especially during COVID-19, where hoaxes spread massively. Moreover, a fact-checking organization needs to be more selective in choosing claims based on check-worthiness criteria, including Cek Fakta Tempo.co. The study described how Cek Fakta Tempo.co determine the check-worthiness of a claim during the COVID-19 pandemic. The study was conducted on case study methods to describe the dynamics and process during a claim selection. The data collection process occurred during February-July 2021, using an in-depth interview with Tempo.co fact-checkers, documentation, and literature study. The study found that Cek Fakta Tempo.co fact-checking methodology consists of three stages, pre-examination, fact-checking process, and post-examination. Moreover, the check-worthiness of a claim is determined at the pre-examination stage by conducting editorial meetings that rely on several considerations. The consideration includes five substantive criteria (viral claims, speaker impact, urgency, proximity, and intention) and also digital tools obtained from the external collaboration.
\end{abstract}

Keywords: Debunking; Fact-checking; Check-Worthy Claims; COVID-19; Hoax

\begin{abstract}
Abstrak
Jurnalisme pemeriksaan fakta hadir dengan tujuan untuk memperbaiki kualitas informasi, termasuk pada masa pandemi COVID-19 yang rentan terhadap hoaks. Meski begitu, penyebaran hoaks yang begitu masif menuntut lembaga pemeriksaan fakta untuk lebih selektif dalam memilih klaim berdasarkan kriteria check-worthiness, termasuk di antaranya Cek Fakta Tempo.co. Penelitian ini menguraikan bagaimana Cek Fakta Tempo.co menentukan checkworthiness sebuah klaim dalam masa pandemi COVID-19. Penelitian mengandalkan metodologi studi kasus untuk mendeskripsikan proses dan dinamika yang terjadi dalam penentuan check-worthiness klaim. Pengumpulan data berlangsung pada Februari-Juli 2021, melalui wawancara terhadap tim Cek Fakta Tempo.co, dokumentasi artikel debunking seputar COVID-19, dan studi pustaka. Penelitian menemukan bahwa metodologi pemeriksaan fakta Cek Fakta Tempo tersusun atas tiga tahap, pra-pemeriksaan, pemeriksaan fakta, dan pascapemeriksaan. Check-worthiness ditentukan pada tahap pra-pemeriksaan, dengan pelaksanaan rapat redaksi yang berdasarkan sejumlah pertimbangan, seperti lima kriteria substansi (viralitas, dampak penutur, kegentingan, proximity, dan intensi), serta bantuan perangkat yang diperoleh dari kolaborasi dengan pihak eksternal.
\end{abstract}

Kata Kunci: Penyanggahan; Cek Fakta; Klaim Check-Worthy; COVID-19; Hoaks 


\section{Introduction}

As a major event that is complex and impacts various sectors of life, the COVID19 pandemic is ideally vulnerable to attacks by fake news (Brataas, 2018; Lupton \& Willis, 2021; Monggilo, 2020b). The drastic change in the situation at the beginning of the emergence of the COVID-19 pandemic then resulted in uncertainty and confusion in the community, especially when access to information and knowledge about the pandemic was still very limited (Woda, Birowo, Vidiadari, \& Nuswantoro, 2021). This is also exacerbated by non-transparent, anti-science attitudes and the rise of controversial statements from the government and community leaders (Almuttaqi, 2020). As a result, people seem to be forced to understand and interpret the meaning of information that is constantly flooding social media platforms and chat applications (Rahmawati, Mulyana, Lumakto, Viendyasari, \& Anindhita, 2021). These situations have made fake news attacks rampant during the COVID-19 pandemic.

In this case, journalism needs to function as a medium of information and a means of social control, where the press monitors the circulating information and verifies it. (Kusumaningrat \& Kusumaningrat, 2017). The purpose of this function is for the public to obtain credible information. In line with Yu et al. (in Monggilo, 2020a), accurate information is the answer people want in the face of a pandemic. One of the alternatives offered is fact-checking, which is allegedly one of the genres in digital journalism.

Fact-checking, as PolitiFact stated when it won the Pulitzer award, is part of a new era of journalism, which is the embodiment of the watchdog in the digital age (Graves, 2013). Meanwhile, the working principle of fact-checking is almost the same as the preparation of journalistic works in general, except that fact-checking journalism specifically targets the purpose of refuting a claim and explaining the truth that ideally needs to be known by the public (Luengo \& García-Marín, 2020; Nurlatifah \& Irwansyah, 2019).

In general, the practice of fact-checking relies on a methodology that consists of 3 stages. Referring to Mantzarlis (2019), the three stages are (1) discovery of claims originating from the internet, (2) fact-checking through source searches and in-depth research, and (3) writing refuting articles, drawing conclusions on claims, and broadcasting the articles to the public.

In practice, fact-checking journalism is generally carried out by media institutions, communities, and governments that work collaboratively and rely on multiple sources. Currently, Indonesia has many fact-checking institutions, but only six have obtained IFCN certification. The six institutions are Tirto.id, Liputan6.com, Tempo.co, MAFINDO, Kompas.com, and Suara.com ("IFCN Code of Principles," nd; Monggilo, 2019).

In the COVID-19 pandemic, the massive amount of fake news circulating is challenging for fact-checkers. The reason is that not all objective claims circulating on the internet are worthy or important to be examined (Hassan, Arslan, Li, \& Tremayne, 2017). In this case, the fact-checker is required to prioritize certain claims that have a high publicity value based on considerations of the feasibility of a claim to be checked (check-worthiness).

The concept of check-worthiness in fact-checking practice was introduced by Hassan, Arslan, Li, \& Tremayne (2017) in research that resulted in the ClaimBuster platform. This fact-checking automation tool has the ability to select claims based on certain algorithms that have been compiled in a database. The research starts from the argument that not all checkable claims meet the check-worthy nature. 
One of the fact-checking institutions in Indonesia that empirically writes about the considerations used in screening claims obtained before being examined is Tempo.co. This is shown on the Tempo.co Cek Fakta (Fact Check) methodology page which asks whether the topic is important to the public. Against the claims that were collected by the fact-checking team.

Furthermore, to prevent the spread of fake news during the COVID-19 Pandemic, Tempo.co's Fact Check is one of the institutions that actively conducts fact checks and publishes debunking articles about COVID-19 issues. Therefore, this study examines how Tempo.co determines the check-worthiness of a claim obtained, especially during the COVID-19 pandemic, which is full of uncertainty.

Based on the background that has been described, this study raises the question of how does Tempo.co determine the check-worthiness of a claim related to COVID-19? Answering these questions, this study aims to describe the processes and dynamics that occur in the Tempo.co Fact Check newsroom in determining the check-worthiness of a claim related to COVID-19.

Within the scope of the study of communication science in Indonesia, there are few studies that specifically describe the fact-checking methodology used by factchecking institutions. Therefore, the researcher views that the study of check-worthiness related to the fact-checking methodology is unique and different from the topic of factchecking research in Indonesia that has been done before. Furthermore, the methodological aspect cannot be separated from a series of fact-checking practices, so it is important for this aspect to receive attention in academic studies.

\section{Method}

This study relies on a qualitative approach that focuses on obtaining in-depth knowledge of the factors and elements that determine the check-worthiness of a claim. Furthermore, the case study method is used to describe the processes and dynamics that occur within the Tempo.co Fact Check organization to determine the check-worthiness of a claim related to COVID-19.

The choice of case study as a research method is based on its ability to explain a phenomenon and its dynamics in depth. In this case, Tempo.co, in particular the process and dynamics of determining check-worthiness that occurs in the editorship of the Fact Check channel, is interpreted as an interesting phenomenon to be described in depth.

A newsroom, holistically, can be seen as an organization. This is because the newsroom meets the organization's criteria, which, according to Tanjung et al. (2021), is a container filled by a group of people who work together to achieve a goal.

In this study, the Tempo.co Fact Check newsroom has a common goal of producing a debunking article, which in its preparation involves decision-making activities, namely the selection of claims to be examined. Referring to Epstein (in Greene González, 2017), the practice of broadcasting news is the outcome of a decision. This implicitly defines that journalistic work ideally is a mirror that displays media organizations' principles, expectations, hierarchies, and interests. Therefore, it is interesting for the researcher to explain the dynamics and processes that occur in the descriptive description of the case study.

The research runs in two stages. The initial stage takes place in October 2020January 2021. At this stage, the researcher conducts initial observations to see the variety of disclaimer content around the COVID-19 issue and prepares a research design. Meanwhile, the second stage will take place in January 2021-June 2021 and 
consists of data collection, analysis, and writing research reports.

The data used in this study came from (1) the results of interviews with the Main Editor of Tempo Media Lab and the Fact Check Coordinator arranged in the editorial of Tempo.co Fact Checks, (2) Documentation studies of Tempo.co Fact Check debunking articles related to COVID-19 throughout 2020, (3) Study of literature in the form of books, journal articles, and online sources to support data findings from points (1) and (2). The data found were then analyzed in three stages of analysis, namely data reduction, categorization, and drawing conclusions.

As a limitation, this research only focuses on the context of fact-checking as a stream of digital journalism and does not discuss the technology or algorithm used to determine the check-worthiness of a claim.

\section{Results and Discussion}

\section{Dynamics and Factors Influencing the Determination of Check-Worthiness}

Since its launch in 2018, Tempo.co's Fact Check channel has specifically carried out fact-checking activities and published articles refuting claims circulating on the internet. Apart from publishing refuting articles, Tempo.co also hopes that public figures will be more responsible for the claims made.

In general, the fact-checking stage by the Tempo.co Fact Check team is not much different from the outline of the fact-checking methodology described by Mantzarlis (2018) through a systematic procedure composed of three stages, namely preexamination, fact-checking, and post-examination -inspection. All activities were carried out by the Tempo.co Fact Check team online, long before the COVID-19 pandemic occurred.

The process of screening a claim takes place at the pre-claim examination stage. Screening a claim, in addition to aiming to select check-worthy claims, also plays a role in facilitating the work of journalists to focus on examining articles with high urgency for review.

Regularly, Tempo.co's fact-checkers work online in a virtual newsroom. This stage begins with the search for claims by each fact-checker. In finding claims, factcheckers rely on a number of sources, such as (1) monitoring and identification with the help of tools, (2) findings from Tempo internal parties other than fact-checkers, and (3) citizen reports.

Furthermore, the claims that have been found are submitted in an editorial meeting to determine whether the claims will be examined or not. In determining the checkworthiness of a claim, Tempo.co's fact-checkers are influenced by considerations from within and outside the institution. The explanation above about the pre-fact-check stage by the Tempo.co Fact Check team can be described as follows. 


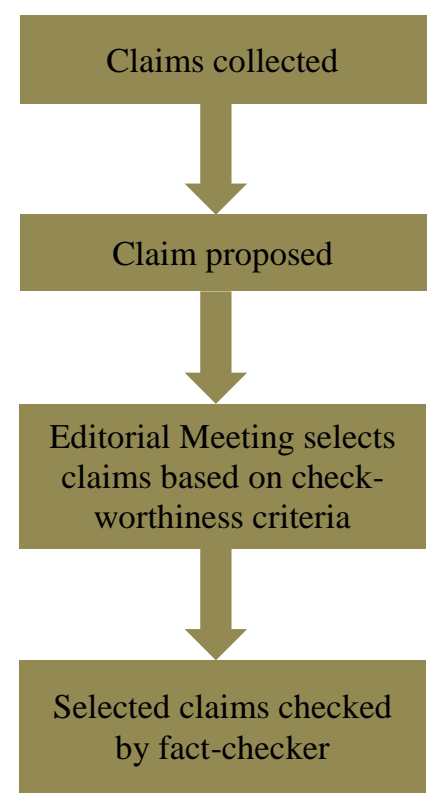

Figure 1. Pre-fact Check Stage by Tempo.co

The practice of editorial meetings conducted by fact-checkers reflects the organizational nature adopted by Tempo.co. Decision making-in this case, the determination of the check-worthiness of the claim that is carried out collectively, whether consciously or not, is influenced by the experience, knowledge, and principles held by each individual involved in the team. Shockley-Zalabak (2015) stated that decision-making in organizations involves individual premises against more general values so that members of the organization can accept these premises.

The result of these premises shows at least five substantive considerations that the Tempo.co Fact Check team relies on when determining the check-worthiness of a claim. The five considerations are (1) the virality of the claim, (2) the impact on the public, (3) the urgency of the situation, (4) proximity to the public, and (5) the intention of the claimant.

1. The first criterion is the virality of a claim. This criterion stems from the argument that a viral claim should ideally have a greater impact on the audience's knowledge.

2. The second criterion is the impact of speakers on the public, who assumes that public figures have the power to shape people's knowledge and perceptions of a phenomenon.

3. The third criterion used by Tempo.co in determining check-worthiness is urgency, which starts from the view that the rebuttal article needed by the public is information related to claims that are relevant to the situation in society at that time.

4. In line with the third criterion, proximity is a further consideration that prioritizes claims with momentum and geographical proximity to the operational area of the fact-checking agency. This criterion is commonly used to consider two claims that meet the urgency criterion.

5. Lastly, Tempo.co determines the check-worthiness of a claim based on the sentiment carried in the narrative of the claim. From the sentiments conveyed, 
it will be seen what the purpose of the hoax maker. In this case, claims made with a narrative of hostility cornering certain groups have more power to cause chaos and deceive the public.

The five substantive considerations used to assess check-worthiness are derived from the collectively understood principles of journalism and the intuition of Tempo.co journalists derived from their experiences. Even so, these five considerations are not absolute considerations to determine the check-worthiness of a claim.

As an organization, Tempo.co's Fact Check decision making is also indirectly influenced by the surrounding environment. As stated by Miller (2012), an organization in its dynamics and processes is always side by side with other organizational environments. This causes the consideration of the check-worthiness of claims not only to come from within the institution but also from outside the Tempo.co's Cek Fakta (Fact Check) editorial room.

An example of influence from outside the organization is the collaboration with the Facebook Journalism Project, which facilitates third-party fact-checkers with dashboards and CrowdTangle tools that can be used to monitor viral content on social media. The CrowdTangle platform is also accompanied by a description of views, likes, comments, and shares owned by content. Therefore, the Tempo.co's Fact Check team can measure the virality of content through features as shown in Figure 1.

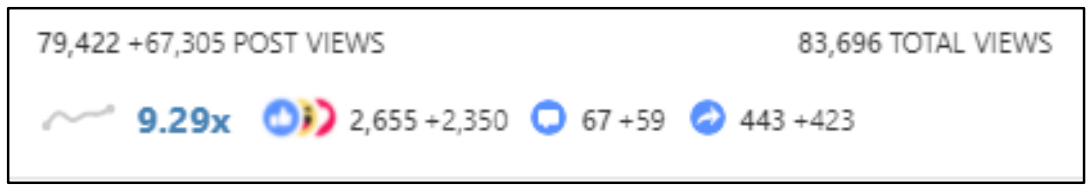

Figure 2. Reach Screenshot post on CrowdTangle Platform (CrowdTangle.com, 2021)

In addition, the check-worthiness of a claim is also considered through the collaboration between Tempo.co and MAFINDO through the Cekfakta.com platform. The platform displays the claims refuted by fact-checking institutions in Indonesia, particularly the six IFCN-verified institutions. Furthermore, each rebuttal article uploaded on Cekfakta.com displays the number of fact-checking institutions that have published articles refuting the claim.

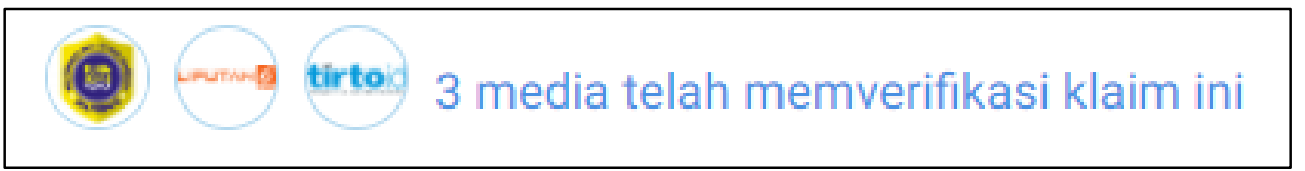

Figure 3. Information on the Disclaimer Article Published by Cekfakta.com

(Cekfakta.com, 2020)

The information presented by the platform guides the Tempo.co's Fact Check team to prioritize examining claims that have never been examined by other factchecking agencies. The determination of check-worthiness, which is carried out manually by the Tempo.co's Fact Check Team with the considerations described previously, implies the absence of a fact-checking automation device that can filter check-worthy claims.

The considerations used by Tempo.co in selecting a claim are admittedly not the most perfect option, but the most effective way that can be done at this time. Even so, the method used by Tempo.co is not without consequences. As an organization, 
Tempo.co holds values that ideally influence the work of journalism published so that it may involve individualistic or collective bias in the claim selection process. This is in line with Epstein's statement (in Greene González, 2017) that the image displayed by the news is a product of the organization itself.

\section{Tempo.co's Response to Fake News Attacks during COVID-19 Pandemic}

Tempo.co realized the surge in fake news at the start of the COVID-19 pandemic as a problem that could potentially cause chaos if it did not get serious treatment. Long before COVID-19 was confirmed in Indonesia, Tempo.co through the Fact Check channel, published a refuting article entitled "Is it true that the emergence of the Corona Virus is related to China's treatment of Uighur Muslims?". Referring to the Tempo.co archive, the article is dated January 27, 2020, and was uploaded as an effort to raise public awareness of the epidemic that has begun to infect countries around Indonesia.

Tempo.co's actions in this regard are in accordance with the role of the media in times of crisis, not only overseeing the handling but also anticipating the impact that will be caused by a crisis and after the crisis occurs. (Monggilo, 2021a, 2021b; Nugroho \& Sulistyorini, 2018). Furthermore, Tempo.co's Fact Check efforts to oversee the COVID-19 pandemic through fact-checking practices are strengthened by an international collaboration initiated by IFCN called the CoronaVirusFacts Alliance. Refer to Palomo \& Sedano(2021), a form of collaboration offered by the CoronaVirusFacts Alliance in the form of a reference database facility in the form of articles refuting claims that have been published by fact-checking institutions around the world who are members of the collaboration.

"Led by the International Fact-Checking Network (IFCN) at the Poynter Institute, the \#CoronaVirusFacts / \#DatosCoronaVirus Alliance unites more than 100 factcheckers around the world in publishing, sharing, and translating facts surrounding the new coronavirus. The Alliance was launched in January when the spread of the virus was restricted to China but already causing rampant misinformation globally. The World Health Organization now classifies this issue as an infodemic - and the Alliance is on the front lines in the fight against it." (CoronaVirusFacts Alliance, n.d.)

In publishing articles related to COVID-19, Tempo.co sees an opportunity in dealing with the COVID-19 pandemic. The publication of rebuttal articles when information about COVID-19 began to mushroom was realized that it had increased traffic to the online news portal Tempo.co. This phenomenon is in accordance with research conducted by Quandt \& Wahl-Jorgensen (2021), which stated a surge in information consumption by universal audiences, especially online news portals, during the COVID-19 pandemic. However, the novelty of the COVID-19 issue is recognized as a challenge for the Tempo.co Fact Check team. Limited information and the lack of reference sources often hinder the fact-checking process and the preparation of rebuttal articles.

Furthermore, other challenges faced by Tempo.co are the flow of information and the spike in the number of claims that need to be examined. Fact-checker Tempo.co admitted that he had been overwhelmed in examining claims regarding COVID-19 because claims were examined without check-worthiness considerations, relying only on the assumption that any information related to COVID-19 was considered important and critical to be known by the public. To deal with this, the Tempo.co Fact Check team then relied on check-worthiness considerations in every claim related to COVID-19 that was found and avoided claims that had already been checked for re-verification. 


\section{Implementation of Check-Worthiness Determinants on Claims around COVID-19}

The higher the interaction between content and the audience, the wider the impact caused as a result of that interaction. This argument then makes the viral content of content become Tempo.co's criteria in selecting the content to be examined. Linking virality with the pandemic, the novelty of the COVID-19 issue has attracted public attention. This is reflected in the source of claims regarding COVID-19, which were denied by Tempo.co. In rebuttal articles, fact-checker Tempo.co often writes down the reach of content as an indicator of virality. For example, a snippet of the narration of an article entitled "[Facts or Hoaxes] is it true that the person who is having seizures in this video is a Corona Virus Patient?"

"As of this writing, the post has been commented on more than 1,600 times, responded to more than 1,700 times, shared more than 13 thousand times, and viewed more than 1.3 million times" (Ningtyas, 2020)

Even so, there is no fixed number to measure the virality of a claim. In a number of uploads, Tempo.co continues to upload claims that have low reach or do not include the reach of the content at all. Furthermore, the check-worthiness criteria of a claim, according to Tempo.co, also pay attention to the impact caused by the claimant on the community. In this case, Tempo.co looks at whether the narrative uses public figures who are claimed to have said certain opinions or whether the claims were actually made by public figures.

In dealing with the crisis caused by COVID-19, public figures are expected to have the ability to guide the public in facing the crisis with strategic steps and useful information (Monggilo, 2020b). This is due to their ability to form public perception and knowledge of a phenomenon. These reasons then make the claims submitted directly or profiteer certain public figures are check-worthy and need to be investigated for truth. Furthermore, one of the seven classifications of fake news, according to Wardle(2017), is imposter content, which is commonly linked to public figures in fake news.

The third criterion used by Tempo.co in determining the check-worthiness of a claim is urgency. This is inseparable from the function of the press, which should report on the current situation to meet the audience's information needs (Abrar, 2015). In the context of fact-checking, the claim is carried out by selecting claims that are critical to a situation. This argument is the basis for Tempo.co to consider the urgency of the issue as a consideration for the check-worthiness of a claim. In seeing how this is implemented, the researcher compares articles about COVID-19, which were refuted by Tempo.co in January 2020 and March 2020.

Table 1. Number of Articles against Tempo.co in January and March 2020

\begin{tabular}{ccc}
\hline Month & Disclaimer articles related to COVID-19 & Total articles \\
\hline January 2020 & 13 & 53 \\
\hline March 2020 & 45 & 58 \\
\hline
\end{tabular}

Based on the findings, rebuttal articles about COVID-19 published by Tempo.co in January 2020 were 13 articles. The other articles were dominated by issues of flooding, the Malaysia-China conflict, and the General Elections Commission (KPU). On the other hand, rebuttal articles about COVID-19 dominated Tempo.co's Fact Check uploads in March 2020 as many as 45 articles. The comparison of the focus of the disputed topics between the two months was in accordance with the conditions in 
Indonesia at that time. It is known that COVID-19 was only confirmed in Indonesia in early March 2020, while January 2020 was the momentum used by Tempo.co to spread awareness regarding the COVID-19 outbreak for the Indonesian people, along with the findings of COVID-19 cases in countries around Indonesia.

Linked to the urgency, a series of events related to COVID-19 could have occurred in the near future. Therefore, it is important for Tempo.co to prioritize claims that are geographically and timeliness close to the current COVID-19 momentum in Indonesia. For a long time, the concept of proximity has remained one of the considerations for news values by media organizations, alongside other criteria such as impact, urgency, and conflict (Parks, 2019).

One example of an article that meets the proximity criteria is the article entitled "Wrong, Covid-19 Vaccine Changes DNA and Causes Lifelong Genetic Defects" which was published in December 2020, as a response to claims about vaccines circulating not far from the momentum of the arrival of the Sinovac Vaccine in Indonesia on December 6,2020 , as well as the issuance of permits for the emergency use of the COVID-19 Vaccine in a number of countries (Aida, 2020; Verdiana, 2020).

Finally, another criterion that Tempo.co considers in determining the checkworthiness of a claim related to COVID-19 is the sentiment contained in the narrative of a claim. In this context, a major event is supposed to be vulnerable to being targeted by irresponsible parties to utter hate speech and cause riots. According to the statement from the Head of Team I Japelidi (in Martaon, 2020), issues of ethnicity, religion, race, and intergroup are the dominant topics in hoaxes around COVID-19. This is in line with Kim \& Kesari (2021), who stated that the issue of discrimination and hate speech, especially against Chinese ethnicity, is one of the problems that has developed and is growing during the COVID-19 pandemic. Take, for example, a rebuttal article titled "[Facts or Hoaxes] is it true that the Wuhan Corona Virus is China's Leaked Biological Weapon?"

In the article, Tempo.co refuted the claim that COVID-19 was a biological weapon made in China. The claim, which was uploaded by a Facebook user, carries a provocative tone that also corners China with unfounded accusations.

"...there is a high possibility that the Chinese government will spread it throughout the world after discovering the anti-Coronavirus fax and is a powerful weapon for the Chinese government to attract money from all over the world by selling vaccines. We hope that the government will be more careful to monitor more strictly importers importing products from China. It is not impossible for China to send the virus in other forms or in the form of cosmetic drugs. (cosmetic) or the like..." (Tempo.co, 2020)

In a crisis, every group in society ideally works together to get through a difficult situation. Therefore, conflict and hostility are the last things one wants to happen. This is what makes Tempo.co view articles with sentiments that corner certain parties as being check-worthy in the issues surrounding COVID-19. This is done to minimize the occurrence of conflicts that can hinder the handling of the pandemic.

\section{Conclusion}

The drastic change in the situation by the COVID-19 pandemic has resulted in a crisis that impacts various sectors of life. The digitization that occurs in society makes the internet an alternative to obtain and disseminate information. However, the rapid flow of information and the difficulty of distinguishing credible information from fake 
news are vulnerable to causing a virus that is no less dangerous than the Coronavirus itself.

In this situation, one of the ways that media organizations and communities can do is to conduct fact checks and publish articles refuting claims related to COVID-19. This fact-checking practice has become the implementation of journalism as a watchdog in the digital era. In practice, fact-checking is carried out by an institution that operates in a systematic procedure and relies on the collaboration of technology and human devices.

Even so, the fact-checking agency should ideally be wise in selecting a claim to be examined. It aims to prioritize check-worthy claims and it is important to be informed to the public. One of the institutions that already have the check-worthiness criteria in selecting claims is Tempo.co, which selects claims based on at least five criteria for assessing claims and referrals sourced from collaboration with external parties.

Tempo.co's response to the COVID-19 pandemic began with efforts to raise public awareness of the current situation. Furthermore, the application of the five assessment criteria for claims regarding COVID-19 has made refuting articles published by Tempo.co have the ability to guard the public in dealing with the pandemic.

\section{Acknowledgments}

The appreciation is presented to the Research, Publication, and Community Service Grant of the Faculty of Social and Political Sciences, Universitas Gadjah Mada in 2021 for supporting the conduct of this research. Furthermore, the researchers also send their gratitude to the Department of Communication Sciences, Universitas Gadjah Mada for the assistance and facilities provided during the research.

\section{References}

Abrar, A. N. (2015). Analisis pers teori dan praktik (5th ed.). Yogyakarta: Cahaya Atma Pustaka. Retrieved from https://opac.perpusnas.go.id/DetailOpac.aspx?id=67478

Aida, N. R. (2020). 6 negara yang setujui penggunaan vaksin Covid-19 Pfizer. Kompas.com. Retrieved from www.kompas.com/tren/read/2020/12/12/192800465/6-negarayang-setujuipenggunaan-vaksin-covid-19-pfizer?page $=$ all

Almuttaqi, A. I. (2020). Kekacauan respons terhadap Covid-19 di Indonesia. Retrieved October 28, 2020, from The Habibie Center Insights website: http://habibiecenter.or.id/img/publication/66f28c42de71fefe1c6fcdee37a5c1a6.pdf

Brataas, K. (2018). Crisis communication (1st ed.). New York: Routledge.

Cekfakta.com. (2020). [SALAH] “Minum kopi 3 x sehari untuk menangkal Covid-19”. Cekfakta.com. Retrieved from cekfakta.com/focus/5045

CoronaVirusFacts Alliance. (n.d.). Fighting the Infodemic: The \#CoronaVirusFacts Alliance. Retrieved June 26, 2021, from www.poynter.org/coronavirusfactsalliance/

CrowdTangle.com. (2021). Tangkapan layar jangkauan artikel Facebook via CrowdTangle. Retrieved June 24, 2021, from apps.crowdtangle.com/covid19/boards/covid-19indonesia

Graves, L. (2013). Deciding what's true (Columbia University). Columbia University. https://doi.org/10.7312/grav17506-006

Greene González, M. F. (2017). The newsroom: A space of decision making. In The Newsroom: A Space of Decision Making. 
Hassan, N., Arslan, F., Li, C., \& Tremayne, M. (2017). Toward automated factchecking: Detecting check-worthy factual claims by claimbuster. Proceedings of the ACM SIGKDD International Conference on Knowledge Discovery and Data Mining, Part F1296, 1803-1812. https://doi.org/10.1145/3097983.3098131

IFCN Code of Principles. (n.d.). Retrieved August 22, 2021, from www.ifcncodeofprinciples.poynter.org/know-more/the-commitments-of-the-codeof-principles

Kim, J. Y., \& Kesari, A. (2021). Misinformation and Hate Speech: The Case of AntiAsian Hate Speech During the COVID-19 Pandemic. Journal of Online Trust and Safety, 1(1), 1-14. https://doi.org/10.54501/jots.v1i1.13

Kusumaningrat, H., \& Kusumaningrat, P. (2017). Jurnalistik: Teori dan praktik (8th ed.). Bandung: PT Remaja Rosdakarya.

Luengo, M., \& García-Marín, D. (2020). The performance of truth: politicians, factchecking journalism, and the struggle to tackle COVID-19 misinformation. American Journal of Cultural Sociology, (0123456789). https://doi.org/10.1057/s41290-020-00115-w

Lupton, D., \& Willis, K. (2021). COVID society: Introduction to the book. In D. Lupton \& K. Willis (Eds.), The COVID-19 crisis: Social perspectives (1st ed., pp. 3-13). New York: Routledge. https://doi.org/10.4324/9781003111344

Mantzarlis, A. (2019). Pemeriksaan Fakta. In C. Ireton \& J. Posetti (Eds.), Journalism, "fake news" \& disinformation (pp. 97-114). Paris: United Nations Educational, Scientific, and Cultural Organization. Retrieved from https://unesdoc.unesco.org/ark:/48223/pf0000368022

Martaon, A. T. (2020). Isu politik, SARA, dan kesehatan mendominasi hoaks. Medcom.id. Retrieved from https://www.medcom.id/nasional/politik/dN60LaPkisu-politik-sara-dankesehatan-mendominasi-hoaks

Miller, K. (2012). Organizational communication: Approaches and Processes (6th ed.). Boston: Wadsworth.

Monggilo, Z. M. Z. (2019). Praktik Pemeriksaan Fakta. In Jurnalisme, "Berita Palsu”, \& Disinformasi (Konteks Indonesia) (pp. 24-31). Jakarta: United Nations Educational, Scientific, and Cultural Organization.

Monggilo, Z. M. Z. (2020a). Komunikasi publik pemerintah masa Covid-19: Telaah kritis sistem informasi publik. In W. Mas'udi \& P. S. Winanti (Eds.), Tata Kelola Penanganan COVID-19 di Indonesia: Kajian Awal (1st ed., pp. 274-299). Sleman: Gadjah Mada University Press. Retrieved from https://digitalpress.ugm.ac.id/book/257

Monggilo, Z. M. Z. (2020b). Sistem informasi publik Covid-19: Telaah konten chatbot dalam melawan gangguan informasi masa pandemi. In N. Kurnia, L. Nurhajati, \& S. I. Astuti (Eds.), Kolaborasi Lawan (Hoaks) Covid-19: Kampanye, Riset, dan Pengalaman Japelidi di Tengah Pandemi (1st ed., pp. 323-351). Yogyakarta: Program Studi Magister Ilmu Komunikasi UGM. Retrieved from https://literasidigital.id/books/kolaborasi-lawan-hoaks-covid-19-kampanye-risetdan-pengalaman-japelidi-di-tengah-pandemi/

Monggilo, Z. M. Z. (2021a). Banyak bencana banyak hoaks, bagaimana memverifikasinya? In H. J. Margianto, Z. M. Z. Monggilo, A. Adzkia, \& D. Yudiawan (Eds.), Memahami bencana alam di Indonesia: Peran media dan cara melawan hoaks bencana (pp. 54-62). Jakarta: Aliansi Jurnalis Independen. Retrieved from aji.or.id/read/buku/75/memahami-bencana-alam-di-indonesia.html 
Monggilo, Z. M. Z. (2021b). Pemberitaan mitigasi yang terlupakan. In H. J. Margianto, Z. M. Z. Monggilo, A. Adzkia, \& D. Yudiawan (Eds.), Memahami bencana alam di Indonesia: Peran media dan cara melawan hoaks bencana (pp. 31-39). Jakarta: Aliansi Jurnalis Independen. Retrieved from aji.or.id/read/buku/75/memahami-bencana-alam-di-indonesia.html

Ningtyas, I. (2020). [Fakta atau hoaks] Benarkah orang yang kejang-kejang dalam video Ini adalah pasien virus Corona? Tempo.co. Retrieved from https://cekfakta.tempo.co/fakta/610/fakta-atau-hoaks-benarkah-orang-yangkejangkejang-dalam- video-ini-adalah-pasien-virus-corona

Nugroho, S. P., \& Sulistyorini, D. (2018). Komunikasi bencana : membedah relasi bnpb dengan media. In Pusat Data, Informasi dan Hubungan Masyarakat, Badan Nasional Penanggulangan Bencana. Retrieved from https://bnpb.go.id/buku/komunikasi-bencana-membedah-relasi-bnpb-denganmedia

Nurlatifah, M., \& Irwansyah, I. (2019). Fact-checking journalism sebagai platform kolaborasi human and machine pada jurnalisme digital. Jurnal Komunikasi, 13(2), 121-134. https://doi.org/10.20885/komunikasi.vol13.iss2.art1

Palomo, B., \& Sedano, J. (2021). Cross-media alliances to stop disinformation: A real solution? Media and Communication, 9(1), 239-250. https://doi.org/10.17645/MAC.V9I1.3535

Parks, P. (2019). Textbook News Values: Stable Concepts, Changing Choices. Journalism and Mass Communication Quarterly, 96(3), 784-810. https://doi.org/10.1177/1077699018805212

Quandt, T., \& Wahl-Jorgensen, K. (2021). The Coronavirus Pandemic as a Critical Moment for Digital Journalism: Introduction to Special Issue: Covering Covid-19: The Coronavirus Pandemic as a Critical Moment for Digital Journalism. Digital Journalism, 9(9), 1199-1207. https://doi.org/10.1080/21670811.2021.1996253

Rahmawati, D., Mulyana, D., Lumakto, G., Viendyasari, M., \& Anindhita, W. (2021). Mapping disinformation during the Covid-19 in Indonesia: Qualitative content analysis. Jurnal ASPIKOM, 6(2), 222. https://doi.org/10.24329/aspikom.v6i2.907

Shockley-Zalabak. (2015). Fundamentals of organizational communication (9th ed.). New York: Pearson Education Inc.

Tanjung, R., Mawati, A. T., Ferinia, R., Nugraha, N. A., Simarmata, H. M. P., Sudarmanto, E., ... Silalahi, M. (2021). Organisasi dan manajemen (1st ed.). Medan: Yayasan Kita Menulis.

Tempo.co. (2020). Keliru, vaksin COVID-19 ubah DNA dan sebabkan cacat genetik seumur hidup. Tempo.co. Retrieved from https://cekfakta.tempo.co/fakta/1169/keliru-vaksin-covid-19-ubah-dna-dansebabkan-cacat-genetik-seumur-hidup

Verdiana, B. M. T. (2020). Kedatangan vaksin Covid-19 Sinovac di Indonesia jadi sorotan media asing. Liputan6.com. Retrieved from https://www.liputan6.com/global/read/4427197/kedatangan-vaksin-covid-19sinovacdi-indonesia-jadi-sorotan-media-asing

Wardle, C. (2017). Fake news. It's complicated. Retrieved June 29, 2021, from https://firstdraftnews.org/latest/fake-newscomplicated/

Woda, B. E., Birowo, M. A., Vidiadari, I. S., \& Nuswantoro, R. (2021). Pandemic journalism: A study of Covid-19 news coverage on detik.com. Jurnal ASPIKOM, 6(2), 235. https://doi.org/10.24329/aspikom.v6i2.906 